
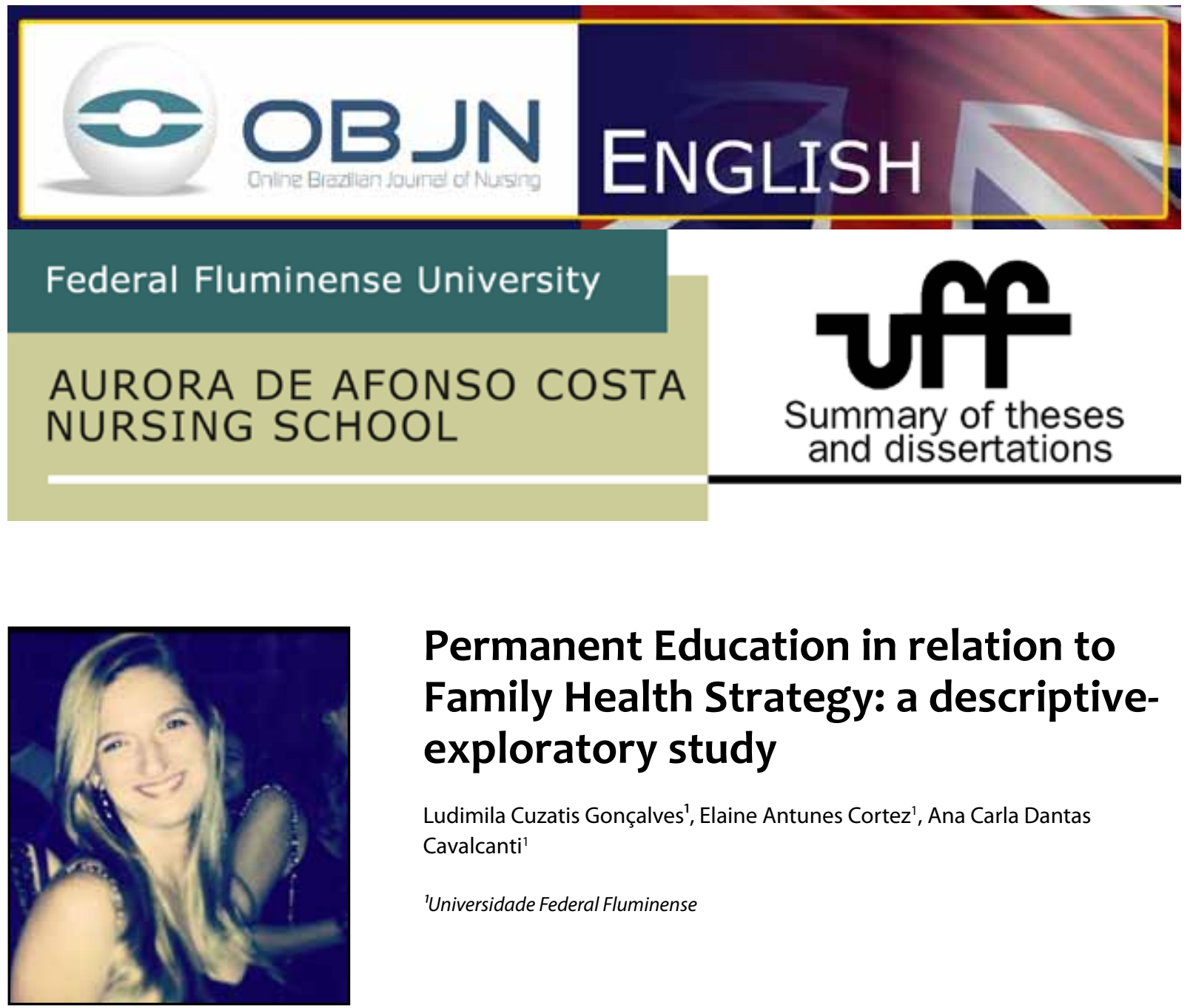

\title{
Permanent Education in relation to Family Health Strategy: a descriptive- exploratory study
}

\author{
Ludimila Cuzatis Gonçalves', Elaine Antunes Cortez' ${ }^{1}$ Ana Carla Dantas \\ Cavalcanti $^{1}$ \\ 'Universidade Federal Fluminense
}

\section{ABSTRACT}

Study of Permanent Education (PE) in relation to Family Health Strategy (FHS).

Issue: the existence of conflict between professionals and authors about the concepts of health education processes and the impact of these conflicts on the implementation of PE.

Aims: to identify the concept of PE as understood by the multiprofessional FHS team; to experiment with a technology with the group in order to enlarge the concept of PE; to develop a PE experience within FHS. Method: field study, descriptive, exploratory, with qualitative approach.

Results: the study produced three categories: Permanent Education in the daily practice of health services: concept understood by professionals: the Health Ministry policy. Discussion: the concept of PE became clearer to the majority of the professionals who participated in the intervention.

Conclusion: the experiment was significant and gave the possibility for the team to consider and rethink the unit working process.

Descriptors: Family health; Primary Health Care; Education. 


\section{INTRODUCTION}

The present study approaches the Permanent Education in Health (PEH) in relation to Family Health Strategy (FHS). The issue that led to the development of this research came from the perception by the authors, in practice and in research, of the existence of conflicts between the assistance professionals and some authors about the concept of the health education process, and the possible impact of this conflict on the implementation of PHE. ${ }^{(1)}$ Recently published studies show the existence of difficulties and obstacles to the implementation of permanent education in some public health service scenarios in Brazil; and professionals of different categories do not know the concept of PHE. ${ }^{(1)}$ Therefore, our research issue comprehends the fact that many professionals who take part in primary health confound the concepts of permanent education and continued education and the $\mathrm{PEH}$ practices become nonexistent in those scenarios.

\section{AIMS}

To identify the concept of PE as understood by the multiprofessional FHS team; To experiment with a technology within the group to enlarge the concept of PE; To develop a PE experience within the FHS.

\section{METHOD}

A field study, descriptive and exploratory with quality approach undertaken in a basic unit in Rio de Janeiro city. The subjects were professionals of all categories who work at the unit. In the first phase, the data were gathered by applying a questionnaire with an open question about the concept of permanent education.
In this phase, 26 professionals completed the questionnaire. In the second phase, seven permanent education workshops were developed in which 13 professionals took part. The proposal was the construction of a conceptual map about $\mathrm{PEH}$ in the first meeting, and another one in the last meeting in order to compare and evaluate the workshops on the answers given by the professionals. In the third phase of the research, the questionnaire used in the first phase was reapplied to the 26 initial participants, in order to evaluate the individual answers and the impact of the workshops. The research was approved by Ethics Committee in Research of Rio de Janeiro city under number157/2012.

\section{RESULTS}

The questionnaire data were analyzed according to the content analysis (Bardin)..(2) As a result, a number of categories came up, such as: "Permanent education on a daily basis within the health service: concept brought by the professionals and the Health Ministry policy"; "Permanent education and continued education: different concepts and complementary practices" and "Permanent education, disease prevention, health promotion and education in health: concepts distinction."The description of the categories was done and the analysis of the data was founded on Theoretical Referential by Paulo Freire. ${ }^{(3)}$ Regarding the analysis of conceptual maps, it was founded on PEH Brazilian Policy.

\section{DISCUSSION}

In terms of the analysis of the permanent education concept, it was verified that, before the workshops, few professionals would define $\mathrm{PEH}$ in accordance with the proposal of Health 
Ministry policy. Many confounded the concept of PEH with the concept of continued education, and others, when defining $\mathrm{PEH}$, presented the concepts of disease prevention, health promotion and education in health. After the workshops it was verified that the concept of $\mathrm{PEH}$ had become clearer to the majority of the professionals who participated in the intervention. In relation to the conceptual map, it was rectified more than ratified, showing the importance of the workshops. The product of this study includes: technology applied and evaluated by the workshops, and as sub-products, the conceptual maps and the proposal for the implementation of PEH in the unit. ${ }^{(4)}$

\section{CONCLUSION}

Understanding the concepts of educational processes in health and discussing them with the multiprofessional team is of great importance so the PEH can be effectively implemented on a daily basis services. The experience lived was significant, and made possible for the team consider and rethink the working processes of the unit.

\section{REFERENCES}

1. Peixoto LS, Gonçalves LC, Costa TD, Melo CMT, Cavalcanti ACD, Cortez EA. Educação permanente, continuada e em serviço: desvendando seus conceitos. Enfermería Global. 2013; 29 (1):324-40.

2. Bardin L. Análise de conteúdo. Lisboa: Edições 70; 2009.

3. Freire P. Pedagogia da autonomia: saberes necessários à prática educativa. São Paulo: Paz e Terra; 2011.

4. Ministério da Saúde (Brasil). Política Nacional de Educação Permanente em Saúde. Brasília: MS; 2009

Date of presentation: August 09, 2013 - Nursing School Aurora de Afonso Costa, Universidade Federal Fluminense.

Examiners: Elaine Antunes Cortez, Prof. Dr. Ana Carla Dantas Cavalcanti, Prof. Dr. Marilda Andrade, Prof. Dr. Florence Romijn Tocantins.

Reference: Gonçalves LC. Educação Permanente no contexto da Estratégia de Saúde da Família: estudo descritivo-exploratório. Niterói. Dissertação [Mestrado em Enfermagem] - Escola de Enfermagem Aurora de Afonso Costa da Universidade Federal Fluminense; 2013.

Received: 30/08/2013

Revised: 02/09/2013

Approved: 04/09/2013 